\title{
The Critique of Methodology: Nationalism and Discipline Construction of Global Governance Research
}

\author{
Zhenye Liu
}

Published online: 3 October 2012

(C) CEEUN 2012

\begin{abstract}
The various difficulties which the human knowledge system are facing in being used to interpret the new issues of globalization and global governance, are traced to methodological level to find the crux of the problem, this lies at the heart mythology of methodological nationalism. Methodology nationalism artificially divides human integral knowledge into domestic/international, internal affairs/diplomacy, self/other. It sticks to the stance of the "National Center Theory", stresses on the absolution of national sovereignty, autonomy and self-sufficiency, stressed on the supremacy of self values and takes it as the universal values. In this paper, based on the critical approaches to the critique of nationalistic methodology, the author explores the methodology of globalism or "nationalism under the globalism perspective" and the possible approaches to the construction of disciplinary knowledge system of global governance. Globalism Methodology stresses the integrity of the human knowledge system, consciously recognizes the relativity of the national sovereignty, emphasizes on significance of the universal values and the same importance of the roles of international mechanisms and non-state actors. This provides an important methodological guidance for global governance research. Under the guidance of globalism methodology, the construction of the knowledge system of global governance research subject should follow a holism, interdisciplinary and multi-paradigm path. The holistic knowledge framework includes the basic theories and methodology of global governance. The interdisciplinary research approach of global governance contains at least the disciplinary knowledge of economics, political science, and moral philosophy, which contains the interdisciplinary interpretation paradigm include: (1) the interpretation paradigm of Global Political Economy, (2) the interpretation paradigm of Global Politics, (3) the interpretation paradigm of Global Ethics.
\end{abstract}

\footnotetext{
Z. Liu $(\bowtie)$

Institute for Globalization and Global Issues,

China University of Political Science and Law, Beijing, China

e-mail: zhenye.liu@163.com
} 
Keywords Methodology nationalism - The globalism methodology · Global Governance Research

\section{Introduction}

Like any subject knowledge of human knowledge system is produced at a particular time, the emergence of global governance research is also the result of the requirements of globalization and global governance age. On the one hand, the consequences of globalization and global governance dilemma urgently need us to find a solution. On the other hand, our existed knowledge about international issues is not available to answer the problems of globalization and global governance age. So, develop a new research field, propose a new theory paradigm and even create a new subject knowledge system should been put on the agenda of human knowledge development. Exploring the subject knowledge system of global governance precisely reflects the above-mentioned needs of global age.

\section{Methodology Nationalism Critique}

Existed human knowledge system is facing various dilemmas when it interprets the new issues raised by globalization and global governance. The root of these dilemmas is methodology nationalism's myth. ${ }^{1}$ Methodology nationalism regards nation-state as the basic unit of human political life in international arena, regards the distinction between nation-states, which is constituted according to the natural distribution, as the established starting point of human knowledge construction. ${ }^{2}$ However, globalization and its consequences have an unprecedented impact on the existed human knowledge system, which regards nation/territory state as the starting point of human knowledge. Therefore, in order to reconstruct human knowledge system of globalization and global governance age, we need to break the methodology nationalism's myth, and replace it with a new methodology.

\section{(1) Methodology Nationalism}

Methodology nationalism is mainly proposed by well-known German political philosopher Ulrich Beck. This concept emphasizes the nation as the core, emphasizes the priority of the nation-state when achieving its political and economic interests and cultural and ethical values, and rejects the interests and values of other.

Firstly, under the domination of methodology nationalism, traditional social science, which take territory and border as the standard to divide the extension category and boundary of the human social science knowledge research, artificially

\footnotetext{
${ }^{1}$ Shengjun Zhang, "Striving for a More Just World", Collected Papers of Global Governance and Global Studies Construction, August 21-22, 2011, Institute of Globalization and Global Issues, China University of Political Science and Law, pp. 40-41.

${ }^{2}$ More critique on methodology nationalism see Ulrich Beck, Macht and Anti-macht in Global Age (Chinese Edition), Guangxi Normal University Press, 2004, pp. 44-48.
} 
divides human integral knowledge into domestic/international, internal affairs/ diplomacy, self/other. This method makes human artificially eliminated the relevancy of any "extrinsic variable" besides self, and make self value obtained the priority and domination relative to other and "outsider" when construct knowledge system, and puts other and "outsider" in the position of marginalization, oppression and instrumentality.

Secondly, methodology nationalism emphasizes the absoluteness, independency and self-sufficiency of state sovereignty. Methodology nationalism assumes that nation-state has supreme authority and ability, which is not only able to deal with the impact of external factors on domestic affairs in accordance with the supremacy of self-interest, but also able to across-the-board cope various internal demands. Sovereignty is inalienable, not negotiable and inflexible. Sovereign state has the self-sufficiency and the ability to solve all kinds of problems and demands it faced.

Thirdly, methodology nationalism insists upon nation-centralism, emphasizes nation-state have absolute leading authority in internal and external affairs. Methodology nationalism thinks that, in internal affairs, the nation-state monopoly on the use of violence and provides internal security, legal order and social security; in external affairs, it provides integral security. Therefore, only the nation-state is the most important role, while the other actors, such as market actors, international organizations and NGOs, have dependency to nation-state. "Nation-state has satisfied the supreme demand of human social organization and order, to rebuild any hierarchical authority structure beyond nation-state system is costly and unnatural", 3 a state-centrist directly said Table 1.

Fourthly, methodology nationalism deny the importance of universal ethics and universal values, emphasizes the supremacy and importance of self values. Meanwhile, it ignores the distinction between self and other, and largely put self values as universal values. Methodology nationalism follows the principle of "a winner-takes-all", emphasizes zero-sum ethics, and treats universal values as insignificant or instrumental thing at most.

\section{(2) The Limitations of Methodology Nationalism}

Reined in border and sovereignty, methodology nationalism simply emphasizes the validity of state-centrism. In the age of globalization and global issues is heavily emerging, and human interdependency is growing, methodology nationalism increasingly shows its deficiencies and limitations. Specifically, it includes the following aspects.

Firstly, modern science-tech revolution broke the old space-time structure, which was simultaneously appeared with nation-state system, and connected people worldwide. Thus, modern science-tech revolution fundamentally changed the old space-time structure within which human constructs its knowledge system. With the developments of information technology, nuclear technology, space technology and technology in global age, the human society has become a whole on a global scale,

\footnotetext{
3 Zhenglin Wang, "International Political Order and International Relations Theory", Chinese Social Sciences Quarterly, Spring/Summer Volumes, 1997.
} 
Table 1 A Comparison between the Methodological nationalism and the Methodological Globalism

\begin{tabular}{|c|c|c|}
\hline & Methodological nationalism & $\begin{array}{l}\text { Methodology Globalism (or } \\
\text { "Nationalism under Globalism } \\
\text { Perspective) }\end{array}$ \\
\hline $\begin{array}{l}\text { Framework of } \\
\text { Knowledge } \\
\text { System }\end{array}$ & $\begin{array}{l}\text { Dichotomy of: Internal/External; } \\
\text { Domestic Affairs/Foreign Affairs; } \\
\text { Self/Others }\end{array}$ & $\begin{array}{l}\text { Integrity Knowledge System: such as Global } \\
\text { Politics; Global Political Economy; Global } \\
\text { Sociology; Global Public Administration; } \\
\text { Global Public Financial, etc }\end{array}$ \\
\hline $\begin{array}{l}\text { State } \\
\text { Sovereignty }\end{array}$ & $\begin{array}{l}\text { Absoluteness, Autonomy, and } \\
\text { Self-Sufficiency of the } \\
\text { Sovereignty; Zero-Sum Games } \\
\text { between Sovereignties }\end{array}$ & $\begin{array}{l}\text { Relativity of Sovereignty, Transference of } \\
\text { Sovereignty; Cooperation and Coordination } \\
\text { between Sovereignties; and the Expansion of } \\
\text { the Abilities of Sovereignty }\end{array}$ \\
\hline $\begin{array}{l}\text { Actors of } \\
\text { Governance }\end{array}$ & Exclusive State Actors & $\begin{array}{l}\text { International Organizations; International } \\
\text { Regimes; International Laws and Norms; } \\
\text { NGOs and Multinational Corporations }\end{array}$ \\
\hline $\begin{array}{l}\text { Culture and } \\
\text { Value }\end{array}$ & $\begin{array}{l}\text { Deny the Importance of University } \\
\text { Ethics and University Values; } \\
\text { Emphasize the Supremacy of Self } \\
\text { Values; Ignore the Diversities } \\
\text { between Self and Others; Pursue } \\
\text { Ethics of Exclusion }\end{array}$ & $\begin{array}{l}\text { Recognize the Significance of University } \\
\text { Values; Admit the Difference and } \\
\text { Diversities between Individuals; } \\
\text { Coexistence of Values between Self and } \\
\text { Others }\end{array}$ \\
\hline
\end{tabular}

"global thinking, local action" has become a reality of human life in the modern time. The thought and methodology of sate-centrism will undoubtedly face new challenges.

Secondly, with increasingly global interdependence, the boundaries between internal and external, domestic affairs and foreign affairs, self and others become increasingly blurred. The global economic interdependence is the most prominent performance of global interdependence, global interdependence in the field of production, trade, investment and financial enhanced mutual restraint and policy coordination between countries in a large extent, which lead to an interconnection between domestic affairs and foreign affairs. The global economic interdependence strengthen the trend of internationalization of domestic affairs and internalization of foreign affairs, domestic affairs in traditional sense increasingly influenced, if not intervened, by the international community, and international factors can also cause domestic linkages and reactions simultaneously. In the political field, all kinds of new security concepts, international norms of human rights and environmental standards increasingly influence to the governance of domestic affairs; similarly, in the economic field, American subprime mortgage crisis rapidly evolved into a global financial crisis in the age of global interdependence, in turn, the governance of the global financial crisis has a profound impact on domestic economic policymaking. The indistinctness of the boundaries between domestic and foreign affairs, the emergence of supranational norms, etc., are changing the traditional statecentrism profoundly, and promoted us to reconstruct the knowledge system of observation and interpretation the world.

Thirdly, Global interdependence and the overall expansion of economic globalization make the autonomy of nation-states facing unprecedented challenges. In economic globalization process, nation states' autonomy significantly reduced in 
the field of economic development and making economic and social policies. In the political field, international norms of human rights, environmental standards and the weapons of mass destruction control norms, etc., increasingly play an important role. The domestic policies making of nation states are facing challenges of intervened by increasing international norms within many political areas. In front of these challenges, nation states can not completely retreat back to the old path of self-enclosed. In order to adapt to the new requirements of global interdependence and global governance, we need a comprehensive reconsideration of the state centrism Paradigm and approaches from the theoretical framework and thinking.

Fourthly, the solution to the urgency of global issues and crises, is "global problems require global solutions", 4 which leads the abilities of self-help and selfsufficiency of nation states increasingly undermined. The methodological nationalism believe that the anarchy of international society led to a security dilemma between countries and a zero-sum games between countries' interests, nation states can only rely their own strength to achieve self-interests, common interests and cooperation in international politics is not reliable. However, the common interests of human beings increasingly highlight with the urgency of various global issues. In the face of challenges of global issues, any country can not cope with and solve it alone, and this situation objectively requires nation states move towards dialogue and cooperation. Nowadays, the worldwide global crisis, such as ecological imbalance, environmental pollution, resources shortage, the spread of drugs and AIDS epidemic, greatly weakened the capacities for self-help and self-sufficiency of nation states. To solve global issues, we must replace thinking and methods of nationalism with global thinking and methods, and rethinking the world we are facing to.

All in all, in an age predominated by nation states, the construction of human knowledge system is hard to break through the constraints of the methodological nationalism. However, nowadays, more then ever before, the life of human society has presented a new scene: Revolution of science and technology changes rapidly each day, globalization and interdependence development in greater depth, solving global issues and crisis is imminent, human beings are trying to break the existing knowledge system and thinking framework to seek new governance patterns. Although nation state is still the most prominent governance actor, the cooperation between countries, international common norms and the participation of non-state actors, etc., are also cannot be ignored. As a result, reconsideration and beyond the traditional methodological nationalism and construct a kind of methodological globalism perspective and knowledge system become an inevitable requirement in nowadays.

\section{Breaking Down the Myth of Methodological Nationalism, and Constructing Methodological Globalism or "Nationalism Under Globalism Perspective"}

Breaking down the myth of methodological nationalism, help us to understand and answer a series of new problems faced by human beings in the changing era of

\footnotetext{
${ }^{4}$ Ulrich Beck, Macht und Gegenmacht im Globalen Zeitalter, (Chinese Edition) Guangxi Normal University Press, 2004, Chapter 2.
} 
globalization and global governance. The methodological nationalism stressed the absoluteness of the nation-state sovereignty, and emphasized the supremacy of the nation-state interests, furthermore, it's accustomed to observing and analyzing international issues from the perspective of nation/territorial state. Accordingly, Global governance, as the method to deal with the consequences of globalization, has to find the coordinates in the supremacy of national sovereignty and the supremacy of the national interest, the only result is to make global governance as a arena of competition of nation interests. The methodological nationalism contradicts the purpose of solving global issues. If human beings attempt to explore ways to solve the global issues, it's necessary to get rid of the plight of this methodological nationalism, and to establish a kind of methodological globalism or "nationalism under globalism perspective". That means transcending the constraints of nation/ territorial states on the basis of overcoming the limitations of nation/territorial states and interest groups, and recognition the common interests of human community, to understand and explore the solutions of new problems raised by globalization and global governance with a global vision and the position of human beings' common interest. The establishment of such a methodology makes globalization and global governance with a philosophical ontological significance of being-it-self. Humanity as a whole and its common interests transcending nation/territorial state has become the theory origin which we deal with problems caused by globalization and global governance.

Specifically, the methodological globalism (or "nationalism under globalism perspective") should include following aspects:

Firstly, the methodological globalism emphasizes the connection and integrity of human community around the world, stresses the construction of human knowledge system ought to break down the barriers between internal and external, domestic affairs and foreign affairs, self and others, and instead of global knowledge system. In this way, "the traditional view that" external factors ", such as the global risk, global standards, supranational participants, African and Arab world conditions of life and human rights abuses, etc., will become "internal variable". 5

Secondly, the methodological globalism admit the sovereignty ability of nation states, meanwhile, however, it consciously recognition the relativity of national sovereignty. The methodological globalism argued, the effectiveness of national independence of policy making is doubtful in the age of globalization and interdependence; any country could deal with the challenges only by adapting to the external environment and adjusting their policies. The nation state has been unable to deal with the challenges of global issues and global financial crises separately. Strengthening cooperation between countries, coordinating policies each other, enhancing the international norms and rules, promoting international co-governance actions by international regimes, have become required options of upgrading governance capacity of every country. Therefore, the self-restraint and self-transference of sovereignty has become an inevitable trend of the nation states to fulfill the responsibilities and expand the ability of sovereignty in the age of globalization.

\footnotetext{
${ }^{5}$ Ulrich Beck, Macht und Gegenmacht im Globalen Zeitalter, (Chinese edition). Guangxi Normal University Press, 2004, p 45.
} 
Thirdly, the methodological globalism recognize the nation state is still the dominated actors of international relations, meanwhile, however, it particular emphasize the governance functions of non-state actors. The methodology globalism argued, in the age of globalization, the governance functions and authorities of international organizations, international regimes, international laws and international norms are increasingly enhanced with the governance capacities of nation state is increasingly stretched, besides, the NGOs' and multinational corporations' capacities are keep enhancing day by day.

Fourthly, on the basis of recognition and emphasis of the differences and diversities between individuals, methodological globalism emphasizes the significance of universal values. It emphasizes that the relationships of value between oneself and others are mutual tolerance rather than mutual exclusive. The global order is coexistence of the multiplicity rather than settling a given question on a single authority.

In brief, the methodological globalism pays more attention on the integrity of knowledge system, the relativity of national sovereignty, the equal importance of international regimes and non-state actors, and inclusiveness between subjects. It provides us a new perspective of observation and explanation of today's globalization world.

Certainly, we are not going to completely deny the significance of the existence of nation/territorial states when we advocated replacing methodological nationalism with a kind of methodological globalism or "nationalism under globalism perspective". Objectively, "for a long period, the nation-state is still the fulcrum of human social life; any view or action rush to overall beyond nationalism is contrary to the reality" ${ }^{6}$ However, the nation/territorial state has to face a new set of constraints, and is bound to be a series of new changes. Such as the autonomy, selfhelp and self-sufficiency abilities of nation state are weakened, which might lead the sovereignty to become more flexible. Therefore, only if we break down the myth of methodological nationalism, and rethink, reinterpret and reconstruct the knowledge system of globalization and global governance with globalism for reference, can we explore the ways to solve the problems of globalization and global governance.

\section{Under the Guidance of Globalism Methodology, Constructing the Knowledge System of Global Governance Research in the New Age}

Globalism is produced after overcoming the methodology nationalism's deficiency and limitation, it adapts to the requirement new times, provides an important methodology path for interpretation and construct all kinds of human management behavior across national boundaries in the globalization and interdependence era.

\section{Global Governance Research with Globalism Path}

Globalism (or "nationalism within the framework of globalization") provides comprehensive methodology guidance for construct global studies.

\footnotetext{
${ }^{6}$ Cai Tuo, "Globalism and Nationalism”, China Social Science, Vol. 3, 2001.
} 
First of all, the globalism methodology provides overall knowledge framework for the study of global governance subject system. Globalism methodology requires people in observation and interpretation all kinds of human management behavior across national boundaries breaking the dividing lines between domestic/foreign, domestic/foreign, self/other, establishing a global whole theory of knowledge system. Thus, in the whole subject construction, there should be similar to the "Globalology" rather than "Global Studies", 7 and then more emphasis on the integrity of global governance subject system.

Secondly, the globalism methodology provides national sovereignty philosophy as the new thinking for global governance study, a new theoretical paradigm and knowledge framework to explain the national management behavior. Globalism methodology stresses the relativity of state sovereignty and the cooperation and coordination between sovereignty, emphasizing the expansion and extension of the sovereignty ability that requires people to observe and explain the national behavior in the height of philosophy, to build a new era of globalization of international cooperation in the political and national management science.

Third, the globalism methodology provides a non-state political perspective for global governance study. Globalism methodology emphasizes the diversification of managing actors, pays attention to international organizations, NGOs and social network and multinational companies. This requires people in observation and explanation all kinds of human management behavior across national boundaries breaking through the perspective of nationalism, paying attention to the international organizations and other actors' supranational governance and supranational political phenomenon. Globalism methodology also pays attention to "non-state politics ", "public politics" and "social politics" phenomenon caused by the nongovernmental organizations, multinational companies and the social network.

Fourth, the globalism methodology provides a global law frame for global governance study. Global doctrine methodology emphasizes international mechanism, international law and the international standard's core role. This requires people to focus on the management of international system and mechanism of construction when consider governing the global problems, as well as the core role of international law and international norms in global governance, to building a global governance order with "rules as the center".

Fifth, the globalism methodology provides a kind of moral philosophy frame for global governance study. Globalism methodology identifies universal value's significance, admits the differences and diversity between individuals, advocates mutual tolerance rather than exclusive ethical value, which requires people from the ethical viewpoint to consider the relationship between global governance actors while thinking about governance of global problems.

\footnotetext{
7 Xing Cao, "Global Discipline Construction Reflections", Collected Papers of Global Governance and Global Studies Construction, August 21-22, 2011, Institute of Globalization and Global Issues, China University of Political Science and Law, pp. 16-26.
} 
Studying on the construction path problem of global governance knowledge system, many scholars have put forward different construction paths. Professor Cai Tuo puts forward the multidisciplinary-interdisciplinary path, thinking that global governance's object involves many disciplines, "to be politics, law, sociology, economics, culture, communication and management's object of attention and branch of field", so it's construction path can only be multidisciplinary or interdisciplinary path. ${ }^{8}$ Professor Cao Xing argues that it should be followed in the construction of integrity path, i.e. to toward "Globalology" rather than "Global Studies" direction to construct. ${ }^{9}$ Fudan university professor Chen Yugang thinks that it can start with the study of the global relationship, and along the global political path to construct. ${ }^{10}$ Bases on the globalism methodology, this paper puts forward a holistic multi paradigm construction path.

The reason why emphasis on the construct path of holism, on the one hand is highlighted by the Global Methodology of artificial segmentation of human knowledge system to break the domestic/foreign, internal affairs/diplomacy, the other hand, due to global governance research is rooted in the philosophy foundation of globalism methodology - the theory point above of the world as a whole and the common interests of mankind.

The holism path emphasizes the disciplines core concepts and areas of holistic explain and the unity of methodology, global and globalism methodology, the global crisis and the problem, the basic theory of global governance, global governance actors, the system of global governance, global relations and global interests, global regulation and global rule of law constitute the unity of the subject areas of global governance, infrastructure theory and methodology, so that global governance studies to become a holistic discipline of knowledge.

Interdisciplinary multi-paradigm of global governance research path actually stressed that the construction of the path of the subject group. Global governance studies as a discipline level of knowledge, the study mainly points to the globalization phenomenon in reality and its caused by a variety of global issues and crises. The management and governance of the ecological environment, the shortage of resources and energy and governance, the governance of climate change, the governance of development and poverty, the respond to nuclear threats and the control of weapons of mass destruction, as well as human rights, drugs and global public health governance, from substance to said these crises governance like any other social disciplines, related to the allocation of human resources and values. The allocation of human resources and the value of social science research, there are three

\footnotetext{
${ }^{8}$ Cai Tuo, "Global Studies: The Times Call for a New Discipline", Collected Papers of Global Governance and Global Studies Construction, August 21-22, 2011, Institute of Globalization and Global Issues, China University of Political Science and Law pp. 7.

9 Xing Cao, "Global Discipline Construction Reflections", Collected Papers of Global Governance and Global Studies Construction, August 21-22, 2011, Institute of Globalization and Global Issues, China University of Political Science and Law, pp. 16-26.

10 Yugang Chen, "Global Relations and Global Studies", International Observers (Chinese Journal) Vol.1, 2012.
} 
main ways - market configuration (equal allocation of transactions), the authoritative configuration (government redistribution) and ethical considerations configuration (love emotion allocation). Thus, there are three main types of disciplines: economics, political science and moral philosophy. Global Governance Institute concerned on global governance as allocated studies that at least would have a system of three types of global governance research subject knowledge: the economics of global governance (global political economy and global economic governance, global environment/energy economics and governance), as the global governance of the political science research (global political science, global security governance, global executive and global public policy, etc.) and as a moral philosophy of global governance (global ethics research, nuclear ethics research, etc.).

The advantages of multi-paradigm of global governance interdisciplinary research path: first, determined relatively "limited" disciplinary research object and scope for all-encompassing global governance research content, so that the scope and boundaries of global governance research disciplines relatively clear. Second, global governance interdisciplinary characteristics have a relatively clear point. Global governance research and other disciplines of cross mainly produces three major sub-disciplines group, each sub-discipline group, respectively, mainly relying on the scope and methods of the discipline of economics, political science and ethics, so that each sub-group of various sub-disciplines disciplines the core areas of the discipline of knowledge are relatively clear, strong scientific disciplines of knowledge of the various sub-disciplines.

\section{Disciplinary Knowledge System of Holism Global Governance}

Disciplinary knowledge system of global governance research is only in the exploratory stage, but academia has proposed relatively molding disciplines of knowledge, which is the most mature subject knowledge framework proposed by Professor Cai Tuo. ${ }^{11}$ Professor Chen Yugang also proposed a similar global studies subject area of the system. ${ }^{12}$ This paper based on academic results have been combined, the methodology of globalism and holism interdisciplinary multiparadigm construct the path of a holism interdisciplinary multi-paradigm framework. This framework is divided into two main components: the basic theory and methodology, interdisciplinary interpretation paradigm.

\footnotetext{
11 Professor Cai Tuo said, the subject areas of the system include: globalization and anti-globalization, global economy, global politics, global law, global culture and global awareness, global ethics and global value, global issues, global governance, global civil society and the global community, the global system with the global community, the global order, global processes, globality. Cai Tuo, "Global Studies: The times call for a new discipline", Collected Papers of Global Governance and Global Studies Construction, August 21-22, 2011, Institute of Globalization and Global Issues,China University of Political Science and Law, pp. 7.

12 The Professor Chen Yugang has put forward five fields of global research topics: global power, global agenda, ethics and culture, the global order and the coordination between global relations and international relations. Yugang Chen, "Global Relations and Global Studies", International Observers (Chinese Journal). Vol. 1, 2012.
} 
The main content of the basic theory and methodology:

(1) Globalism methodology and global. Global is the result of the continuous development of globalization and human interdependence. It stands for the integrity, the new common quality and characteristics of all human beings, which reflected when treading all human beings as one, all the world as whole and the common interests and values of mankind. ${ }^{13}$ This new quality is all about the object of global governance research. The Globalism methodology stress the integrity and connection of the human society, emphasizing the construction of human being's knowledge system should break the boundaries between the domestic/foreign, internal affairs/diplomacy, self/other, and instead with global knowledge system. Global Methodology admits the sovereignty of nation-state, but consciously agrees that national sovereignty is relative and emphasize governance function of the non-state actors. Globalism methodology emphasized self and other's value is not mutually exclusive but mutually inclusive, the order of global governance is not, but Coexistence.

(2) Globalization, interdependence and global issues. Globalization and global interdependence cause the inter-national and supra-national governance issues, globalization and global issues is the main object of global governance research.

(3) Basic theory of Global Governance. To face and resolve Globalization and global problems require humans to transcend national politics and governing at the global level. The basic theory of global governance includes governance mechanism, global governance, national governance and international governance relations, and the democratization of global governance.

(4) Global governance actor. Including nation-states, intergovernmental organizations and non-governmental organizations, multinational companies, as well as other international actors. Actors of global governance are the one who caused the globalization and global issues, but also the one tried to solve the problems.

(5) System of global governance and the global community. Globalization and global interdependence promote the formation of a global system and global community; global governance actors take the system of global governance and global community as the stage of activities. The relationship between the global governance system and the national system, between the global community, the international community and national society, and global governance system and the operation of the global community are all the important content of global governance research.

(6) Global relations and global interests. Global relations refers to the relationship between the actors of global governance, the core of it is interest relationship. The connotation of global interests or all human being's interests, the relationship between global interests and national interests, the implementation

13 Cai Tuo, "Global Studies: The times call for a new discipline", Collected Papers of Global Governance and Global Studies Construction, August 21-22, 2011, Institute of Globalization and Global Issues, China University of Political Science and Law, pp. 7. 
and maintenance of global interests go throughout all issues of globalization and global governance process.

(7) Global Governance Regulation and the global rule of law. Global governance emphasized the importance of governance mechanisms and rules, therefore the global rule of law go throughout the whole process of globalization and global governance. Global governance mechanisms, governance rules, the international system, international law and the world law constitute the main framework of global governance, and also become the main means and ways of global governance

The interdisciplinary interpretation paradigm:

(1) Interpretation paradigm of the international political economy. With the strengthening of economic globalization, regionalization and interdependence of global economic, the vast majority of cross-border economic issues are beyond the inter-State relations, and become the core issues of the global economic governance. Thus, the global political economy has become an important explanation paradigm of global governance research. There are many research issues of the global political economy, broadly speaking, including the global oil and energy issues, the debt crisis, inflation, global development issues, poverty issues, the global financial crisis, WTO and the IMF and other institutions of global economic governance, the international monetary system and supervision, global and interdependence of regional integration and regional governance, international economic coordination and cooperation in governance issues, all of these issues are the main target of the global economic governance, also the core issues of global governance research.

(2) Interpretation paradigm of the global political science. Including political theory of global governance, global security governance, the non-traditional security issues and global public policy issues

Political theory of global governance is more about the global political changes, such as trying to explore the impact of globalization on national sovereignty, the transformation of global governance mechanism, the governance participation of the state and non-state actors. The analysis of the principle of political science and theoretical approach are the basic research tools of such issues.

Global security governance is basically the traditional security areas of international politics study, but put the common interests of the global human at the core place, broke through the National Center for paradigm of traditional war and conflict theory. In today's global security issues, such as peace studies, the theory of nuclear war, control of weapons of mass destruction, disarmament and arms control, international terrorism and other issues have begun to transcend national center paradigm, become more global. As to the theoretical analysis tools, the theory of peace, just war theory will become important analytical perspectives and tools of global governance research.

As the connotation of security issues greatly expand, the study of non-traditional security issues become to the part of global politics and global governance research. 
General, explored from the philosophical concept of human security, individual security, global security, the Earth system security and so on. They are all about the non-state actors-centric security issues, which broke through the Paradigm of National Center. Generally speaking, environmental security, economic security, cultural security, information security, food security, energy security, and all global issues are related to security issues. These non-traditional security issues related to expertise and analysis tools of political science, economics, sociology, biology, ecology and other disciplines. Sometimes these involved issues are too much scientific that can not simply apply the discipline of the global political science research paradigm. However, the treatment of non-traditional security issues related to the formulation of public policy of the national and global level, thus they also belong to the scope of the study of global public policy and global governance.

(3) Interpretation paradigm of global ethics. Global Ethics is being produced in globalization and the process of global governance. Globalization help to promote global development and at the same time bring out the global inequality and injustice, there is unreasonable, undemocratic governance mechanisms showing up during the process of global governance. When facing the selection of globalization and global governance we not only need a variety of political and economic means to promote the transformation of the global issues of governance, but also need global ethics and common values to standardize and guide the governance behavior of human beings. So, the global ecological ethics, global nuclear ethics, global awareness and global values become important part of the content and subject knowledge system of global governance research. 